DOI: https://doi.org/10.32839/2304-5809/2019-6-70-11

UDC 811.111

Davydovska Nadiia, Dmytruk Olga

Taras Shevchenko National University of Kyiv

\title{
MANIPULATION STRATEGIES CLASSIFIED ACCORDING TO THE PERLOCUTIONARY EFFECT (BASED ON TRUMP'S SPEECHES IN 2018-2019)
}

Summary. This article is devoted to the study of manipulation strategies, used in Donald Trump's speeches in 2018-2019. The identified manipulation strategies were classified according to the perlocutionary effect. The strategies of downshifting, upshifting and neutrality were singled out and analyzed. It was shown that the strategy of downshifting is used to create a negative image of the objects, to undermine their prestige and authority, to show their negative sides and criticize them, to make the objects lose face and influence their actions by means of public opinion and threats. Within the scope of the strategy of downshifting, the tactics of negative connotation, the tactics of insult, the tactics of accusation and the tactics of threat were studied. It was found that in Trump's speeches, the strategy of upshifting is used to create a positive image of the objects, to boost their prestige and strengthen their authority, to show their positive sides and advertise them, to preserve the face and improve the public opinion by means of refuting criticism and self-justification. The strategy of upshifting involves the tactics of positive connotation, the tactics of presentation, the tactics of the positive self-representation, the tactics of refuting criticism and the tactics of self-justification. The strategy of neutrality is used without giving any negative or positive characteristics of the object. It was found that not all tactics are used by Mr. Trump in the researched speeches, the two dominant ones being the tactics of informing and the tactics of delimitation.

Keywords: manipulative influence, strategy of downshifting, strategy of upshifting, strategy of neutrality, tactics, speech manipulation.

Давидовська Н.В., Дмитрук О.В. Київський національний університет імені Тараса Шевченка

\section{МАНІПУЛЯТИВНІ СТРАТЕГІЇ,, КЛАСИФІКОВАНІ ЗА ПЕРЛОКУТИВНИМ ЕФЕКТОМ (НА МАТЕРІАЛІ ПРОМОВ ТРАМПА 2018-2019 РР.)}

Анотація. Дана робота присвячена вивченню маніпулятивних стратегій, використаних у промовах Дональда Трампа, виголошених у 2018-2019 рр. Виявлені маніпулятивні стратегії були класифіковані за перлокутивним ефектом. Було виокремлено та проаналізовано стратегії на пониження, на підвищення та нейтральності. В рамках кожної стратегії було виділено численні тактики. Стратегія на пониження використовується для створення негативного іміджу об'єктів, підриву їх престижу та авторитету, демонстрації їх негативних сторін та критики, для компрометації об'єктів та здійснення впливу на їхні дії за допомогою громадської думки та погроз. Виявлено, що Трамп використовуе тактику негативної конотації, щоб викликати негативне ставлення до небажаних людей і явищ, щоб представити свое президентство як більш успішне в порівнянні з президенством Обами, щоб розкритикувати ЗМІ і звинуватити їх у фральсифрікащії новин, щоб прищепити негативне ставлення до нелегальної імміграції та бездіяльності з боку демократів, щоб осудити пізні аборти. Показано, що тактика образи переважно пов'язана з ІДІЛ, а тактика звинувачення використовуеться також щоб викрити корумпованість та нечесність ЗМІ, та щоб звинуватити зовнішніх опонентів та інших внутрішніх політичних лідерів в економічних труднощах країни. Тактика погрози є крайньою мірою маніпуляції та в основному застосовуеться щодо тероризму. Показано, що стратегія на підвищення використовуеться Трампом для створення позитивного іміджу об'єктів, для підвищення їх престижу та зміцнення їхнього авторитету, для демонстрації їх позитивних сторін та реклами, для збереження репутації та покращення громадської думки шляхом відведення критики і самовиправдання. Виявлено, що Трамп вдається до тактики позитивної конотації, щоб викликати позитивне ставлення до певних людей і явищ, що, як правило, добре позначається на популярності його президентства та його адміністрації або посилюе патріотичні почуття американців і їх національну гордість. Тактика презентації використовується для висвітлення позитивних сторін об'єктів, які є вигідними для пана президента. Тактика позитивної саморепрезентації е однією з найбільш широко використовуваних тактик у промовах Трампа. Ця тактика є надзвичайно корисною для побудови та забезпечення престижу та репутації Президента, оскільки дозволяе йому рекламувати свої власні досягнення і говорити про свої заслуги перед країною безпосередньо чи опосередковано. Тактика відведення критики не дуже часто використовуеться в досліджуваних промовах Трампа, оскільки Президент надає перевагу тактиці самопрезентації, а не виправданню своїх дій. Тактика самовиправдання є найменш використовуваною тактикою у досліджуваних промовах. Вона в основному пов'язана зі ЗМІ. Показано, що стратегія нейтральності використовується без надання будь-яких негативних або позитивних характеристик об'єкта. Було виявлено, що в межах цієї стратегії двома домінуючими тактиками є тактика інформування та тактика розмежування.

Ключові слова: маніпулятивний вплив, стратегія на пониження, стратегія на підвищення, стратегія нейтральності, тактика, мовленнева маніпуляція.

The problem of the article. In recent years, 1 the linguistic research of the phenomenon of manipulative influence on human consciousness is becoming more prominent. Manipulation strategies are widely used by contemporary politicians, which is why the identification of the cases of manipulation and the analysis of the models and mechanisms of the influence of speech on the addressee 
are of utmost importance. It allows to counteract the manipulation and to protect the addressee from the manipulative influence.

The analysis of main researches and publications. Different classifications of manipulation strategies were analyzed, namely those of van Dijk, Maya David, Kenzhekanova, Zhanabekova and Konyrbekova, Kara-Murza, Shawqi K. Ismail, O. Dmytruk, O. Agrasheva, O. Mikhaleva, Y. Dvoynina and others. Van Dijk [3; 4] singled out the strategy of positive self-presentation and negative other-presentation. Maya Khemlani David [2] spoke about different persuasive techniques: metaphor and simile, allusion, lists of three, anaphora or repetition, using specific pronouns for specific purposes, inclusive/exclusive "we". Kenzhekanova, Zhanabekova and Konyrbekova [5] highlighted phonographic, lexical, and grammatical levels of speech manipulation.

Unsolved parts of the general problem. The strategies and tactics of manipulating human consciousness used in the up-to-date speeches of the current president of the USA call for a deeper research. In this work, the manipulative potential of individual tactics and techniques as well as their combinations is scientifically substantiated and investigated, the features of the individual manipulative style of Donald Trump are traced.

The purpose of this article is a comprehensive study and systematization of verbal means of influencing the recipient's consciousness used by Donald Trump in his speeches in 2018-2019.

The main material. For the purposes of this research, we investigated the speeches of the current president of the United States of America Donald Trump. According to the topic of the present paper, we singled out different strategies and tactics of manipulation by means of the continuous sampling method. The revealed examples of the manipulative tactics were grouped and analyzed.

According to O. Mikhaleva [6], the fundamental strategies in speech manipulation are the strategy of downshifting, strategy of upshifting and strategy of neutrality. Each strategy has its own set of tactics. The first type includes: a) tactics of negative connotation (hidden manifestation of the negative attitude towards the object); b) tactics of insult (offending the object explicitly); c) tactics of accusation (public ascription of guilt either for committing reprehensible actions or for personal negative traits, not supported by concrete arguments); d) tactics of impersonal accusation (a more restrained statement of the same kind of guilt as in the tactics of the accusation, without direct reference to the object); e) tactics of exposure (a more specific version of the tactics of accusation, that is, using real facts that confirm the accusation); f) tactics of threat (it is either the object is considered as a potential or real threat, or it is a threatening intention directed at the object).

The strategy of upshifting includes such tactics as: a) tactics of positive connotation (the exact opposite of the tactics of negative connotation); b) tactics of presentation (the presentation of the strongest and the most positive sides of the object); c) tactics of implicit positive self-representation (tactics of presentation regarding the speaker himself); d) tactics of refuting criticism (justification of the performed actions, supported by strong arguments); e) tactics of self-justification (the tactics of refuting the criticism directed at the speaker, mainly aimed at removing the guilt).

The strategy of neutrality includes the most tactics. The most widespread of them are: a) tactics of motivation (the realization of a call to action); b) tactics of provocation (as the extreme degree of the tactics of motivation); c) tactics of cooperation (an appeal to those inviolable ideals, values that are in the focus of speech manipulation); d) tactics of delimitation (finding and further accentuation of discrepancies in positions); e) tactics of informing (statement of real facts without characterizing them), etc. [1].

In the analyzed speeches we detected multiple usage of the abovementioned strategies and tactics and traced their functions and influence on the image of Donald Trump and his administration.

The strategy of downshifting is used to create a negative image of the objects, to undermine their prestige and authority, to show their negative sides and criticize them, to make the objects lose face and influence their actions by means of public opinion and threats. Most tactics are successfully realized in Trump's speeches.

Trump resorts to the tactics of negative connotation to provoke negative attitude to the unwanted people and phenomena. One of the people towards whom Trump expresses negative attitude is John McCain. In one of his speeches [9] Trump attacks McCain posthumously on the Steele dossier, which McCain turned over to the FBI for inspection. Trump claims: "I've never liked him much. ... John McCain received a fake and phony dossier.... And John McCain got it. He got it. And what did he do? He didn't call me. He turned it over to the FBI, hoping to put me in jeopardy. And that's not the nicest thing to do". Trump avoids the direct judgement against McCain, but still gives a subtle feedback and expresses his own opinion, prompting the audience to agree with him.

Another recurring topic in Trump's speeches is the issue of the military veterans and their access to the medical care. Trump prides himself on improving the situation for the veterans by means of enactment of the Veterans' Access to Care through Choice, Accountability, and Transparency Act. At the same time, Trump accuses his political opponents and medical institutions of violating the rights of the veterans by using the tactics of negative connotation: "I got Choice and I got Accountability. Accountability - meaning, if somebody mistreats our vets - for 45 years they were trying - they mistreat our vets, and we say, "Hey, you're fired" [9]. Trump points out that the abovementioned subjects mistreated the veterans, showing his negative attitude towards them. He gives exact numbers and uses repetition to boost validity of his statement.

Among the individuals who fall victim to Trump's criticism we can also find the $44^{\text {th }}$ president of the USA Barack Obama: "Four straight years, the number of U.S. tanks that were budgeted for upgrades was zero. ... That was under your great President Obama. Our military readiness declined and your workforce was slashed by 60 percent. But those days are over" [9]. Competition between the two presidents can be 
clearly observed, as Mr. Trump tries to present his presidency as being more successful and productive than that of Mr. Obama by means of the tactics of negative connotation.

The mass media is a powerful tool of the manipulation of the public opinion and if it publishes negative facts about the president and his policy or the economy of the country, the broad masses of population are very likely to believe them. Thus, Trump counteracts the manipulations used by the press by means of the tactics of negative connotation: "3.1 percent GDP. ... The press tried to make it 2.9. ... The fake news tried to change it but we caught them" [9]. In this passage the tactics of negative connotation is expressed by accusing the press of providing incorrect data and trying to conceal Mr. Trump's achievements.

Trump is also known for his firm policy against illegal immigration, as he put a lot of efforts into securing the southern border of the USA. Trump is convinced that illegal immigration boosts crime, murders and drug abuse [8; 10]. The President uses the tactics of negative connotation in combination with the tactics of informing to instill the negative attitude towards illegal immigration into the audience. "Every week, 300 of our citizens are killed by heroin alone, 90 percent of which floods across from our southern border. ... In the last two years, ICE officers made 266,000 arrests of aliens with criminal records, including those charged or convicted of 100,000 assaults, 30,000 sex crimes, and 4,000 violent killings" [8].

Democrats are the logical political opponents of the Republican president, so they do not escape Trump's attention. Similarly to the role of the politics of the former president Obama, they play the role of the scapegoat in Trump's speeches. Trump claims: "Democrats in Congress have refused to acknowledge the crisis. And they have refused to provide our brave border agents with the tools... Democrats will not fund border security" [8].

Another issue Trump feels strongly about is the issue of abortion. In some states late-term abortion is allowed, but according to Trump: "There could be no greater contrast to the beautiful image of a mother holding her infant child than the chilling displays our nation saw in recent days. Lawmakers in New York cheered with delight upon the passage of legislation that would allow a baby to be ripped from the mother's womb moments before birth" [10]. Again, the tactics of negative connotation is used to condemn late-term abortions.

The tactics of insult is not very widely used in Trump's speeches and few examples were found, for example: "ISIS can no longer claim widespread ownership over local governments in Syria and Iraq. Now, you're always going to have people; they'll be around. They're sick. They're demented" [7]. The insult is directed at ISIS and its people, as Trump calls them "sick" and "demented" because he believes them all to be terrorists. By such name calling, Trump gives the audience clear terms to operate with and encourages them to share his assessment of their actions.

Tactics of accusation is among other tactics that Trump uses against ISIS. As Trump deems ISIS to be the pure evil, he uses rich vocabulary to describe its true nature (= vicious ideology). The President accuses ISIS of proliferating their dangerous beliefs and rules by means of force: "They [ISIS] can no longer control schools to impose their vicious ideology on young children" [7]. Trump accuses ISIS of taking advantage of the small children and growing monsters out of them. It reinforces the image of ISIS as the archenemy and justifies his own aggressive actions in the Middle East.

In continuation of his struggle against the media for influence on the public opinion, Trump resorts to the tactics of accusation, which implicitly verges on the tactics of self-justification: "...I have the fake news hounding me all the time. The fake and phony and corrupt. It's fake. It's corrupt" [9]. Using the tactics of accusation allows Trump not only to protect himself from the negative effects of the unfavorable news reports, but also to discredit the media and to indemnify himself against the future attacks.

The tactics of accusation is also used against external opponents, for example, China: "We are now making it clear to China that after years of targeting our industries, and stealing our intellectual property, the theft of American jobs and wealth has come to an end" [10]. Trump accuses China of being the reason of misfortune for the Americans and of theft. This allows him to blame economic difficulties on the third party and take no responsibility for past struggles of the American economy and at the same time gain favorable position as the savior of the nation and the protector of common Americans from the malicious schemes of China.

Sometimes Trump is not straightforward with accusations and resorts to the tactics of impersonal accusation. For example, in the quotation "In January 2017, only two years ago, ISIS had a vast amount of territory in Syria and Iraq. When I became President, I said, "I want to see what they have". And I looked, and it was a mess. It was a lot" [7] the phrase "it was a mess" does not only describe the situation, but also implies that it is someone's fault that the problem had reached such dimensions, so Trump does make an accusation without mentioning any names, however. Indirectly, he blames his predecessors and opponents for allowing the issue to get out of hand and stresses his decisiveness and resolve to eliminate the threat.

The tactics of threat is not a very commonly used tactics in the researched speeches of Trump. That is a quite extreme measure of manipulation and the President reserves it for the archenemies the terrorists. Talking about the risk of the terrorist attacks on the territory of the United States, Trump resorts to the tactics of threat: "'Well, maybe somebody comes from the area, and they hit us on our homeland". If that happens, they will suffer consequences over here like nobody has ever suffered before" [12]. This tactics allows Trump to present himself as a strong president, ready to protect his people and eliminate any threat to the security of the USA.

The strategy of upshifting is used to create a positive image of the objects, to enhance their prestige and strengthen their authority, to show their positive sides and advertise them, to preserve the face and improve the public opinion by means of refut- 
ing criticism and self-justification. Trump skillfully uses this strategy as a powerful tool of increasing his prestige. Most tactics are successfully realized in his speeches.

Trump resorts to the tactics of positive connotation to provoke positive attitude to certain people and phenomena, which generally serves well the popularity of his presidency and his administration or boosts the patriotic feelings of the Americans and their national pride.

Americans are used to seeing their country strong, so one of the most important points highlighted by the tactics of positive connotation is the army. In one of his speeches, Trump says: "We are rebuilding the American military. ... Over the last two years, we have secured nearly \$1.5 trillion to provide our warfighters the finest aircraft, ships, missiles, and tanks anywhere on Earth. We make the best equipment on Earth" [9]. From this extract we can see that the dominating tactics is the tactics of positive connotation, as all the information provided serves the purpose of instilling the positive attitude towards the development of the military and keeping the nation strong in terms of military resources.

Trump also uses the tactics of positive connotation to encourage those who work to the benefit of the military power of the nation: "What you achieve here at this plant is truly remarkable. ... you restore its unmatched power, strength, and glory with all brand new equipment inside" [9]. Trump expresses his approval of the work done at the plant and compliments them on their skills and professionalism. His ultimate goal is to encourage the workers to keep doing their job, to boost their confidence in the utility of their job and assure them that their work is highly appreciated as well as to get their support as the President of the USA.

In terms of his policy against illegal immigration, Trump uses the tactics of positive connotation regarding his own actions usually in combination with the antithesis: "The border city of El Paso, Texas, used to have extremely high rates of violent crime... Now, with a powerful barrier in place, El Paso is one of our safest cities" [10]. By contrasting the situation before his intervention and after it, he focuses the audience's attention on the positive shifts that took place and on the fact that his politics actually work.

Trump also uses the tactics of positive connotation towards the people close to him and whose positive image benefits him. For example, he uses very flattering and positive words talking about his wife, Melania Trump: "A very popular First Lady and a great person" [12]. The First Lady is very important for the image of the President, so he praises her and keeps her in high esteem.

Tactics of presentation is closely connected to the tactics of positive connotation. Trump tends to use this tactics to highlight the positive sides of the objects that are advantageous to him. For example, "Over the past two years, we have retaken more than 20,000 square miles of land. We have secured one battlefield. And we've had victory after victory after victory, and retaken both Mosul and Raqqa. We have eliminated more than 60 mile high-value ISIS leaders" [7]. In this quotation, Trump points out the positive sides of the successes the Americans achieved in the Middle East.

Not only the military sector is important, but also the economic sphere. Being economic world leaders is of utmost importance to the Americans and their vision of the United States. According to Trump: "The United States is the largest producer-that's happened over the last short period of time - of crude oil and natural gas in the world, surpassing Saudi Arabia and Russia" [9]. Within the scope of the tactics of presentation, the President stresses the advantage the USA has over the other countries in the strategic fossil fuel extraction by means of comparison to the other two top producers.

The tactics of the positive self-representation is one of the most widely used tactics in Trump's speeches. This tactics is extremely useful and helpful for building and securing the prestige and reputation of the President, as it allows him to advertise his own achievements and speak about his services to the country directly or indirectly.

The tactics of implicit positive self-representation is a more indirect way to talk about one's good deeds and implies that the speaker mentions his successes and hints at their positive sides and importance, but does not speak bluntly about them. Trump is a prolific user of such a tactics, for example: "In January 2017, only two years ago, ISIS had a vast amount of territory in Syria and Iraq. When I became President, I said, "I want to see what they have". ... When I took office, one of my very first acts was to go to the Pentagon and ask them to produce and show me a plan to defeat ISIS. Under the new approach we developed, we empowered our commanders in the field, enabled our partners on the ground, and directly confronted ISIS's wicked ideology" [7]. Trump does not attribute all the positive advancement to himself directly, but we can see multiple hints like "When I became President", "When I took office", "Under the new approach we developed, we empowered", which leads us to believe that all of those positive shifts would not have been possible, if it weren't for Trump's presidency.

Continuing the topic of the veterans, Trump proceeds to some actions done for their benefit: "The White House VA hotline has fielded more than 200,000 calls and successfully resolved 93 percent of the concerns our veterans brought to them. And they work very hard. It's been very, very effective" [11]. Again, Trump does not mention his involvement straightforwardly, but he gives positive evaluation of the actions of his administration and it is clear under whose directions it operates.

As was mentioned before, Trump holds economic situation in high regard and in his speeches he skillfully connects all the positive changes and economic breakthroughs to him becoming the president without saying so directly. For example, "After so many years of budget cuts and layoffs, today, jobs are coming back and pouring back, frankly, like never before" [9]. Implementing the tactics of implicit positive self-representation, the President does not say that it was he who changed the situation, but the analogy is clear. To boost the effect Trump uses the comparison between past misfortunes and present unprecedented thriving. 
Another point Trump advertises himself on is that he presents himself as a businessman who knows the worth of money and how to manage it: "I don't want to have them make a big chart because it costs too much. You know, I'm a business guy. They said, "Sir, we could make a big chart". I said, "How much does it cost?" Like it matters. But it matters to me" [9]. Trump implies that this side of his is extremely useful for the presidency, because his experience in the economic sphere serves the country well. If he managed to make his own business work, this means that he knows the price of money and can manage money reasonably.

Within the scope of the tactics of the implicit positive self-representation Trump also tends to tell good things about himself by quoting the conversations he had with other people and those individuals usually praise him on the things he did, for example: "I said, "You know, we didn't break the 3. Oh, that's terrible". They said, "Yes, sir, you did. They just took odd months". I said, "No, no, January to December". 3.1 percent, first time in 14 years. Congratulations. Sort of incredible" [9]. As can be seen in this quotation, Trump conveys positive evaluation of his actions through the words of other people. To top it off Trump uses the tactics of informing to use the favorable data to his advantage and the words with emotive and evaluative component ("incredible").

Another way of the usage of the tactics of the implicit positive self-representation is through the comparison with the previous president, Obama. For example: "Europe is down, Asia is down - a lot of places. Almost every place is down. Except the United States is up. And we're way up. And just think of what that would be. The world goes up; we go up with the world. The world is down, but we still go up. Something is happening. That wouldn't happen under Barack Obama, that I can tell you" [9] In this case, the whole extract is built on the contrast between the United States and the rest of the world and between Trump and Obama.

Trump also likes to point out the phenomenality of his administration, previously unseen achievements and results, especially over a short period of time: "Over the last two years, my administration has moved with urgency and historic speed to confront problems neglected by leaders of both parties over many decades" [10]. The method of comparison becomes prominent here, as Trump once again uses other political forces as a negative background for his own successes.

The tactics of positive self-representation is a more direct way to talk about one's personal merits and implies that the speaker bluntly mentions his successes and explicitly points to his positive sides and achievements.

Trump also uses some categorical statements in the framework of the tactics of positive self-representation, he takes credit for positive things done for the country: "The vets were on my side because I got the job done. I got Choice and I got Accountability" [9]. Trump is not being overly modest in his self-representation and sometimes it causes controversy, but mostly it is eagerly accepted and assimilated.

Another way to use the tactics of positive selfrepresentation is to use the tactics of inclusiveness and presentation and then to narrow it down to only one person: "We approved the Keystone Pipeline. Right? I did that" [9]. Trump uses an inclusive statement about the advancements in the pipeline issue ("We approved the Keystone Pipeline"), but right afterwards he distances himself from his team and directly takes credit for approving the Keystone Pipeline.

Trump also uses the tactics of repetition, particularly, the lists of three, in combination with the tactics of positive self-representation, for example: "We could've taken your jobs, all. If it weren't for me, this place would've been closed. Would have been closed. Would have been closed, fellas" [9]. Trump repeats three times "would've been closed", referring to the tank plant in Lima, as three time repetition has the best psychological effect it terms making people remember the information and believe it [2]. The President proudly takes credit for keeping the plant open and presents himself as the benefactor of his target audience.

Trump also wants his image to appeal to the common citizens and their families, so he pays due attention to social causes and their funding: "I am also proud to be the first President to include in my budget a plan for nationwide paid family leaveso that every new parent has the chance to bond with their newborn child" [10]. In this case, the tactics of positive self-representation is combined with emotive evaluation ("proud to be") and is expressed by means of categorical nomination. Trump also goes on to mention the noble reason of such an action, boosting his popularity among families with young children.

It is also worth mentioning that Trump often uses conditionals to express the unique usefulness of his presidency for the nation. For example: "If I had not been elected President of the United States, we would right now, in my opinion, be in a major war with North Korea. Much work remains to be done, but my relationship with Kim Jong Un is a good one" [10]. The President makes it clear that the peace between the United States and North Korea is exclusively his merit and prognosticates disasters if the situation were any different.

Tactics of refuting criticism is not very commonly used in the researched Trump's speeches, because Trump prefers the tactics of positive self-representation rather than to justify his actions. One of the few examples of this tactics is connected to the finances regarding the construction of the barrier to secure the southern border of the United States: "This barrier is absolutely critical to border security. It's also what our professionals at the border want and need. This is just common sense. The border wall would very quickly pay for itself. The cost of illegal drugs exceeds \$500 billion a year, vastly more than the $\$ 5.7$ billion we have requested from Congress" [8]. Trump anticipates the criticism of his strategy to build a wall, so he presents some arguments in its favor right away. Trump also uses the tactics of categorical nomination (e.g. "This barrier is absolutely critical to border security". etc.) and the tactics of informing. By presenting some figures, Trump refutes criticism connected with the cost of securing the border, as he shows his audience that the benefit is greater than the loss. 
The tactics of self-justification is the least used tactics in the researched speeches. It is mostly connected with the media: "We've created more than almost 6 million jobs since the election. And if I would have said that to the fake news during the campaign, they would've said, "He exaggerates". I'm not exaggerating, but nobody would've believed that could happen. Including almost 600,000 manufacturing jobs" [9]. Trump models the criticism received from the media and justifies himself in front of his audience by providing the numbers and figures and using the tactics of informing. He also resorts to name-calling and attacks the media by claiming that the news is fake.

The strategy of neutrality includes many tactics. The strategy of neutrality is used without giving any negative or positive characteristics of the object. It is mostly used to prompt people to certain actions, to provoke them and incite to a certain type of behavior, to appeal to values and ideals relevant to the target audience, to stress the differences in opinions and positions and to give truthful information without evaluating it or expressing an opinion. Not all tactics are used in the researched speeches, the two dominant ones being the tactics of informing and the tactics of delimitation.

The tactics of delimitation presupposes pointing out the discrepancies in the positions of different subjects. The most widely used method in the framework of that tactics is the usage of the pronouns, for example: "They've really been set back. We're working very hard on the Internet. For a period of time, they used the Internet better than we did" [7]. In this extract, we can see that the pronouns create a clear divide between the two groups, drawing an exact line between "we" and "they". There is a clear contrast between these two groups of people; "we" is opposed to they". Trump stresses this divide without giving it any evaluation, leaving it to the judgement of the audience.

The most important aspect of the tactics of delimitation is that even though it does not provide an opportunity to give the direct evaluation, it sets the stage for further assessment: "They said, "We're closing it". And I said, "No, we're not" [9]. Trump does not to say if the information presented in this extract is good or bad, but it sets the distance between his position and the opposing one and prepares the audience for further imposition of the opinion.

Tactics of informing is widely used in Trump's speeches to provide the information previously unknown to the audience or to draw their attention to relevant facts and figures. The tactics of informing can be followed or preceded by various other tactics, in which case it acquires new meaning and serves the purposes of the companion tactics. Some examples of such instances were analyzed above.

Trump uses the tactics of informing to reinforce the scale of the problems or achievements, which he speaks about. For example: "Veteran suicide is a tragedy of staggering proportions. Hard to believe an average of 20 veterans and service members take their lives every single day. Who would believe that's possible?" [11]. Trump needs to support his allegation about the "staggering proportions" of the issue and he successfully does so through the tactics of informing. Thus, the tactics of informing serves the purpose of adding trustworthiness to Trump's words.
The tactics of informing is also used while talking about economic issues. Trump mentions exact numbers if their interpretation is likely to be positive for his image: "Last year, I signed into law the largest funding bill for the VA in its history, which included $\$ 8.6$ billion for veterans in mental health services" [11]. Here the tactics of informing works well in combination with the tactics of implicit positive self-representation and the tactics of positive connotation. Trump does not give any evaluation to the fact he presents, but the numbers speak for themselves and characterize him in a positive way. The target audience is aware that $\$ 8.6$ billion is a big sum of money and that funding health services for the veterans is a good idea.

Sometimes the tactics of informing is used to present inherently positive information - even if it does not contain any assessment, it is accepted favorably. For example, "Unemployment has reached the lowest rate in half a century. ... More people are working now than at any time in our history - 157 million" [10]. The issue of employment is one of the most crucial ones for the Americans and the information about the positive changes in this sphere is accepted with enthusiasm.

The issue of the illegal immigration is also expressed through the tactics of informing. In this case sinister and worrying data is provided, so that people can assess it on their own and come to the required conclusions: "As we speak, large, organized caravans are on the march to the United States. ... I have ordered another 3,750 troops to our Southern Border to prepare for the tremendous onslaught" [10]. The information presented in the extract is disturbing to the audience, as it threatens their safety, so when at the end Trump informs the people about his counteractions, it incites relief and boosts trust and confidence in the president.

Another way to use the tactics of informing is to present negative facts and statistics to provoke the negative response to the phenomenon. For example, in terms of illegal immigration we find such extracts: "1 in 3 women is sexually assaulted on the long journey north. Smugglers use migrant children as human pawns to exploit our laws and gain access to our country. Human traffickers and sex traffickers take advantage of the wide open areas between our ports of entry to smuggle thousands of young girls and women into the United States and to sell them into prostitution and modern-day slavery" [10]. Seemingly, we have only a compilation of facts, but actually, these facts were selected in such a manner that they create a very grim picture of the migration processes. It helps Trump to present the situation in the way that suits best his policies. Having processed this information, the Americans conceptualize illegal immigrants as the scourge of the United States and a threat to order and safety.

Conclusions. The research proves that manipulation strategies and tactics play an important role in the political discourse, namely in Trump's speeches. The strategies of downshifting, upshifting and neutrality were traced and analyzed in the speeches of the current president of the USA Donald Trump.

The strategy of downshifting is used to create a negative image of the objects, to undermine their prestige and authority, to show their negative sides and criticize them, to make the objects lose face and 
influence their actions by means of public opinion and threats. Trump skillfully uses this strategy as a weapon against his opponents and enemies. Most tactics are successfully realized in his speeches.

The strategy of upshifting is used by Trump to create a positive image of the objects, to enhance their prestige and strengthen their authority, to show their positive sides and advertise them, to preserve the face and improve the public opinion by means of refuting criticism and self-justification. Most tactics are used in his speeches.

The strategy of neutrality is used without giving any negative or positive characteristics of the object. It serves to prompt people to certain actions, to provoke them and incite to a certain type of behavior, to appeal to values and ideals relevant to the target audience, to stress the differences in opinions and positions and to give truthful information without evaluating it or expressing an opinion. It was found that not all tactics are used by Trump in the researched speeches, the two dominant ones being the tactics of informing and the tactics of delimitation.

Further research of the manipulation strategies in Trump's speeches according to the means of manipulation is advocated.

\section{References:}

1. Agrasheva O.E. (2017). Rechevyie manipulyatsii v politicheskom diskurse SShA [Speech manipulations in the political discourse of the USA] [Online resource]. Ogarev-online, № 10. Retrieved from: http://journal.mrsu.ru/ arts/rechevye-manipulyacii-v-politicheskom-diskurse-ssha

2. David M.K. (2014). Language, Power and Manipulation: The Use of Rhetoric in Maintaining Political Influence. Frontiers of Language and Teaching, vol. 5(1), pp. 164-170.

3. Dijk T.A. van. (2006). Discourse and manipulation. Discourse \& Society. SAGE Publications (London, Thousand Oaks, CA and New Delhi), vol. 17(2), pp. 359-383.

4. Dijk T.A. van. (2011). Discourse, knowledge, power and politics. Towards Critical Epistemic Discourse Analysis. Critical Discourse Studies in Context and Cognition. Edited by Christopher Hart. Discourse Approaches to Politics, Society and Culture 43. John Benjamin Publishing Company, pp. 27-64.

5. Kenzhekanova K., Zhanabekova M., Konyrbekova T. (2015). Manipulation in Political Discourse of Mass Media. Mediterranean Journal of Social Sciences MCSER Publishing, Rome-Italy, vol. 6, No. 4, S1, pp. 325-332.

6. Mihaleva O.L. (2004). Politicheskiy diskurs kak sfera realizatsii manipulyativnogo vozdeystviya : PhD thesis : 10.02.01. Irkutsk, $289 \mathrm{p}$.

7. Trump D.J. (2019). Donald Trump Addresses Global Coalition to Defeat ISIS - February 6, 2019. Retrieved from: https://factba.se/transcript/donald-trump-remarks-global-coalition-isis-februray-6-2019

8. Trump D.J. (2019). Donald Trump Addresses the Nation from the Oval Office on the Border Wall - January 8, 2019. Retrieved from: https://factba.se/transcript/donald-trump-speech-oval-office-immigration-january-8-2019

9. Trump D.J. (2019). Donald Trump Delivers Remarks at the Army Tank Plant in Lima, Ohio - March $20,2019$. Retrieved from: https://factba.se/transcript/donald-trump-speech-lima-army-tank-plant-march-20-2019

10. Trump D.J. (2019). Donald Trump Delivers the State of the Union - February 5, 2019. Retrieved from: https://factba.se/transcript/donald-trump-speech-state-of-the-union-february-5-2019

11. Trump D.J. (2019). Donald Trump Signs An Executive Order to Stem Veteran Suicide - March 5, 2019. Retrieved from: https://factba.se/transcript/donald-trump-remarks-veteran-suicide-executive-order-march-5-2019

12. Trump D.J. (2018). Donald Trump Speaks to Troops at Al Asad Air Base in Iraq - December 26, 2018. Retrieved from: https://factba.se/transcript/donald-trump-speech-troops-holiday-visit-iraq-december-26-2018 